\title{
Accommodating Employees with Disabilities: Perceptions of Irish Academic Library Managers
}

Anne-Marie O'Neill

Technological University Dublin

Christine Urquhart

Aberystwyth University

Follow this and additional works at: https://arrow.tudublin.ie/libart

Part of the Library and Information Science Commons

\section{Recommended Citation}

O'Neill, A., Urquhart, C.: Accommodating Employees with Disabilities: Perceptions of Irish Academic Library Managers. New Review of Academic Librarianship. Volume 17, Issue 2, pp. 234-258. 2011. DOI: 10.1080/13614533.2011.593852

This Article is brought to you for free and open access by the TU Dublin Professional Services (including Library Services) at ARROW@TU Dublin. It has been accepted for inclusion in Articles by an authorized administrator of ARROW@TU Dublin. For more information, please contact arrow.admin@tudublin.ie, aisling.coyne@tudublin.ie,gerard.connolly@tudublin.ie.

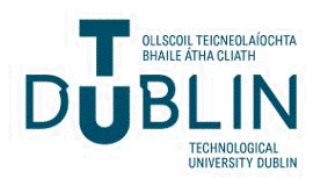


New Review of Academic Librarianship, 17:234-258, 2011

Copyright @ 2011 Taylor \& Francis Group, LLC

ISSN: $1361-4533$ print / 1740-7834 online

DOI: $10.1080 / 13614533.2011 .593852$

\title{
ACCOMMODATING EMPLOYEES WITH DISABILITIES: PERCEPTIONS OF IRISH ACADEMIC LIBRARY MANAGERS
}

\author{
ANNE-MARIE O'NEILL \\ Dublin Institute of Technology, Ireland \\ CHRISTINE URQUHART \\ Department of Information Studies, Aberystwyth University, Wales, UK
}

This research study investigated the views and practice of third level academic library managers in the Republic of Ireland regarding reasonable accommodation of employees with disabilities (as defined in the Irish Employment Equality Act 1998 as amended by the Equality Act 2004).

A mixed methods study (sample of 163 library managers) employed both an online survey (response rate 108/163) and follow-up telephone interviews (23\% of respondents). Questions were based on a literature review.

Library managers were aware of a legal duty to accommodate. A majority of library managers subscribed to the social model of disability rather than the medical model. They were less aware of the needs of employees with less visible disabilities. A small majority of library managers reported the presence of an accommodation procedure at their college. A large majority of library managers would not spend more than 0-10\% of the library budget on accommodation-in practice, this should be sufficient. A small majority believe that a legal obligation to accommodate is necessary. A majority would adopt a graduated approach (informal to formal) in relation to discriminatory conduct.

On the whole, the legislation was working in practice. However, further disability awareness training of staff was required, and further research should examine the views of library staff with disabilities.

Keywords equality, diversity, legislation, Ireland, employees with disabilities, accommodation, academic libraries

\section{Introduction}

In recent years a significant amount of the literature in the field of librarianship has focused on providing greater access to library facilities to clients with disabilities. There has been constructive

Address correspondence to Anne-Marie O'Neill, The Library, Dublin Institute of Technology, 40-45 Mountjoy Square, Dublin 1, Ireland. E-mail: annemarie.oneill@dit.ie 
debate about accessible buildings, ergonomic design of library facilities, and assistive technologies; but, what of individual people with disabilities who wish to work in libraries? Does the concern for accessibility extend to their employment in the library workplace? What is happening in Irish academic libraries to accommodate them in their employment and achieve equality of opportunities?

Section 16(3)(b) of the Employment Equality Act 1998 as amended by section 9 (a) of the Equality Act 2004 imposes a legal duty on employers in the Republic of Ireland to provide reasonable accommodation to enable a person who has a disability (1) to have access to employment; (2) to participate or advance in employment; or (3) to undergo training unless the accommodation would impose a disproportionate burden on the employer. It also states that a person who has a disability must be regarded as fully competent to undertake and fully capable of undertaking, any duties if, with reasonable accommodation provided by his/her employer, s/he would be fully competent and capable of doing so.

This study examines library managers' views and their practice in relation to the provision of "reasonable accommodation" for employees with disabilities in third level college libraries in the Republic of Ireland. It sets out, among other aims, to assess the efficacy of the Employment Equality Act 1998 in implementing reasonable accommodation. Meanwhile, European wide, the working environment is changing. Developments in assistive technologies are making some types of accommodation easier. Legislation throughout Europe is developing to guarantee the rights of people with disabilities to participate. However, discrimination on grounds of disability is not always direct or simple to rectify. The new Equality Act 2010 in the UK aims to simplify and unify existing discrimination legislation. Significantly, it contains among its provisions, a detailed duty to make reasonable adjustments where a person with a disability is placed at a substantial disadvantage, including changing a work practice; providing access to a building; and providing auxiliary aids and services (Section 20).

The aims of the present article are to clarify how Irish academic library managers view problems and opportunities that arise from accommodation of employees with disabilities. Academic libraries have responded well to providing support for 
students with disabilities, but how does that experience translate to supporting employees, particularly those with less visible disabilities? Perhaps sanctions are necessary to enforce compliance with the legislation, or perhaps a more creative approach toward accommodation and integration might be encouraged. These questions were addressed in research that was conducted as a postgraduate Masters dissertation by the first author, under the supervision of the second author.

\section{Background}

Approaches to the Topic of Reasonable Accommodation of Library Employees with Disabilities Revealed

The literature demonstrates three main approaches to the topic of accommodation of employees with disabilities in the library workplace: 1) a positivist approach contained in legislation, case law and codes of practice; 2) a sociological, more illuminative approach revealed in quantitative and qualitative studies of disability practice; and 3) a pragmatic approach revealed in professional journals and Web sites which offer advice as to how an employee with a disability may be practically accommodated in the workplace, for example, the Office of Disability Employment Policy U.S. Department of Labor website, Job Accommodation Network ("JAN"), the IBEC/ICTU Website, Workway, and the Canadian Mental Health Association's Website, Mental Health Works.

The positivist approach reveals the philosophical, historical, and contextual background for the concept of accommodation of employees with disabilities in the workplace. It demonstrates that the rationale of the accommodation concept lies in achieving "equality of opportunity" for all, that is, leveling the "playing field" between employees with and without disabilities (Bruton; Byrne; McCrann and Kelleher; Waddington and Hendriks; Wells). However, legislation provides a minimum as opposed to "best practice" standard for employers, and it appears from sociological studies that some library employers may not be motivated primarily by the minimalist threat of legal liability (Joint, "Disability Issues", 449). 
On the other hand, the sociological studies, (e.g., Burke; Dibben, James, and Cunningham; Smith; Dibben et al.; Uppal; Newton, Ormerod, and Thomas), suggest that, despite the enactment of equality legislation, organizations vary in their commitment to equality of opportunity, with larger organizations, public and voluntary sector disability organizations, and family run businesses where a person acquired a disability, being most likely to be positive in their approach (Newton, Ormerod, and Thomas 612, 618). However, although these studies corroborate these conclusions, they are small in scale, and sometimes dependent on secondary sources.

The pragmatic approach, apparent mostly in twenty-first century Web sites, reveals a significant progression from the 1990s mindset of how best an employer might avoid liability to employees with disabilities (Mancuso; Irving and Kleiner) toward a positive espousal of the matter of accommodation of employees with disabilities. However, the information in the Web sites tends not to be workplace specific, and it is usually left to the individual employer to assess the demands of his/her particular workplace for the individual with disabilities.

\section{Significant Themes in the Literature on Accommodation}

While these three general approaches may be discerned in the literature, there are a number of discrete themes that emerge from within them.

The first is that two main philosophical approaches to disability may be found in the literature. The definition of disability in section 2 of the Employment Equality 1998 as amended is a "medical model" of disability. This model locates the adaptability "problem" within the medical condition of the individual. The "social model" by contrast locates the adaptation difficulty within the social environment and is typically framed as a restriction in the individual's ability to participate by virtue of society's constraints rather than as a medical condition (Hosking, "A High Bar”, 229; Wells, 257-58; Newton, Ormerod, and Thomas, 611). It is increasingly accepted in the literature that the social model facilitates a relatively more positive and inclusive approach to the accommodation of disability (although it may be less helpful in offering insights into non-structural barriers [Newton, Ormerod, 
and Thomas, 611]). Some commentators look to the European Court of Justice to develop a more balanced and inclusive definition of disability through its case law (Wells, 273) while others doubt that it will, pointing to the likelihood of its adherence to the principle of subsidiarity in the interpretation of Council Directive $2000 / 78$ establishing a general framework for equal treatment in employment and education ("the Framework Directive") and its recent implicit acceptance of the medical model in the Chacón Navas case. In that case, the court ruled that a temporary illness did not amount to a disability under the Directive (Hosking, 229) and therefore created conflict between European case law and the more positive rulings of the Irish Labour Court in this regard (O'Mara, 103). By contrast, international organizations such as the World Health Organization, the International Labor Organization, disability organizations such as the Irish Commission on the Status of People with Disabilities and commentators are increasingly adopting the social model as having a more positive effect in changing collective mindsets and achieving equality of opportunity (Conroy and Fanagan, 16-17)

The second theme emerging is that there is judicial insistence that procedures should be in place for delivering accommodation to employees with disabilities in the workplace. Decisions in cases taken before the Equality Tribunal constantly demonstrate that Irish judicial officers and bodies are firm about the requirement for employers to have appropriate policies and procedures in place to deliver reasonable accommodation if required (Boyle $v$. the Department of Social and Family Affairs; An Employee v. Bus Eireann; A Worker [Mr. O] v. An Employer [No. 1]). More recent American literature focuses on the need for dialogue in the implementation of accommodation procedures (Wendt and Slonaker). The Ontario Human Rights Commission in Canada has suggested principles for reasonable accommodation (Mental Health Works). To date, the response in Ireland has been to adopt codes of practice of a general nature (Ireland Department of Finance; Ireland Department of the Environment and Local Government) but the concept of interactive procedures (i.e., involving the employee with a disability in every step of decision making on his/her accommodation), has yet to be introduced in these codes.

The third theme is that there is a need for clear understanding of the costs of accommodation. The initial legislation in 
Ireland was resisted and the "accommodation unless "undue hardship"” provisions of the original Employment Equality Bill 1996 were ruled unconstitutional because of the potentially excessive financial burden accommodation might impose on an employer amounting to a threat to an employer's private property rights (In the matter of the Employment Equality Bill 1996). Currently, following the implementation of the European Framework Directive in Ireland an employer's failure to provide reasonable accommodation can only be justified if it involves a "disproportionate burden on an employer" (Employment Equality Act 1998 s. 16(3) (b) as amended by the Equality Act 2004 s. 9). While the current legislation sets out a number of factors to be taken into account in determining whether a burden is disproportionate, employers are still confused about the real fiscal benchmark. What amounts to a "disproportionate burden" may depend on the level of state support available. The European Court of Justice which is in a position to offer guidance on the term which is used in the Framework Directive seems reticent about challenging employers concerns about costs (Hosking, "Great Expectations," 678). Other commentators seek to quell employers' fears by pointing to the fact that, increasingly, new services and new reduced price technologies are being made available to accommodating employers and stress that, in many cases, it is profitable and beneficial for businesses and society to employ people with disabilities (Aisling Foundation, 4; Christie and Kleiner, 154-55; Nelson and Kleiner, 150; Sahi and Kleiner, 137; Spechler; Wells).

The fourth discernible theme is that some sanction needs to be in place if the duty to provide reasonable accommodation is to be enforced. Currently in Ireland failure to provide reasonable accommodation does not, per se, amount to unlawful discrimination but merely disentitles an employer from arguing that an employee is unable to undertake the duties of the employment ( $A$ Worker [Mr. O.] v. An Employer [No. 1]). It has been argued that failure to accommodate a person with disabilities amounts to denying that person equal opportunities and, therefore, such failure should be regarded as a distinct form of discrimination as is the case in the UK, USA, Australia, and New Zealand (Waddington and Hendriks, 426)

The fifth theme is the view that more should be done to achieve the integration of employees with disabilities in the workplace. Legal commentators point to the need for a "seamless 
package" of "reforming legislation that tracks all phases of a person's development and associated needs" (Byrne, 157). Social scientists emphasize the need to remove both structural and nonstructural barriers to the integration of employees with disabilities in organizations (McCaskill and Goulding; Dibben, James, and Cunningham; Newton, Ormerod, and Thomas). Studies in the library sector advocate that library managers address the impact of the library environment on less obvious disabilities (Joint, "Libraries, Digitisation and Disability"; McCaskill and Goulding). The pragmatists assert that disability awareness training for employers and employees is central to dispelling misconceptions about employees with disabilities (Aisling Foundation; Charles; Forrest)

\section{The Emerging Research Questions}

The research questions emerged primarily from inconsistencies, gaps, and uncertainties in the literature. There seemed significant inconsistencies in the commitment of employers to accommodation in the workplace and in the employer's perceptions of employees with disabilities. There was an absence of information on accommodating library employees (as opposed to library clients) with disabilities, particularly for employees with less visible disabilities. There was a need to examine whether library managers do have accommodation procedures in place. There was also uncertainty surrounding the costs employers were willing to incur in providing accommodation and in relation to the strength of employers' motivation in providing it. The literature also indicated that there was a need for positive action to be taken by employers in relation to accommodation of disability in the workplace in order that equality of opportunity might be achieved.

\section{Methods}

This study employed a mixed method approach comprising a quantitative survey followed by a qualitative telephone interview. The sampling frame for the online survey was selected from staff lists on the Web sites of the college libraries which were subsequently verified by the relevant college library managers. The names of the 271 librarians on the lists were transcribed 
onto cards. To obtain a stratified random sample of the various grades of librarians, the cards were sorted according to grade and each librarian allocated a number within their grade (FrankfortNachmias and Nachmias, 188; Sapsford \& Jupp, 32). An online sample size calculator was used to generate a sample number that would yield a confidence level of $95 \%$ and a confidence interval of 4.85 (Creative Research Systems). Accordingly, it was decided to sample 163 librarians. A calculation was made as to how many librarians would need to be selected within each grade in order, proportionately, to obtain the desired sample; the desired proportion being $60 \%$ of the total number of librarians within each grade (i.e., 163/271). Geoffrey Urbaniak and Scott Plous's computer program, Research Randomizer, was used to generate random numbers to select a random sample within each grade. The sample was selected without reference to whether the librarian had/did not have a disability. Permission was sought from Heads of the college libraries to conduct a survey and subsequent interview. The Head of one college library refused permission and 10 librarians of similar grades from other college libraries were selected at random and substituted for the librarians of that college. After a pilot study of four librarians (for face validity of the questions) minor changes were made to the questionnaire. An e-mail containing a link to an online survey, with an informed consent letter attached, was sent to the e-mail addresses of qualified librarians in the participating libraries in January 2009.

The questionnaire comprised 15 questions (simple classification, dichotomous, vignette, multiple choice, and open in type). The vignette technique presents participants with a scenario and asking them how they would respond when confronted with the circumstances of that scenario (Bryman, 245). Finch (110) and Urquhart (279) indicate that the vignette technique permits sensitive questions to be asked about people other than the participants, and elicits more honest replies. The vignette scenarios were constructed as close to real life scenarios as possible in order to reflect the complexities of real reasonable accommodation responses (Finch, 111).

The final question asked whether participants were prepared to take part in a telephone interview. A semi-structured interview format was used, with a schedule revised after piloting, and participants contacted during working hours at a convenient time. 
Participants were sent an information letter prior to the interview, with a copy of the interview schedule. In the absence of the available technology for recording a mobile telephone conversation, a reflective technique during note-taking was used. This involved offering back in the participant's words the key substance of what they had just said and enabling them to express agreement or disagreement with the notes being taken. This is recognized as good practice in reflective interviewing (Gillham, 35). Notes were amended where the participant indicated, and the interview written up immediately after the interview.

Data collected by the survey was analyzed using the Surveymonkey and Statistical Package for the Social Sciences ("SPSS") software (Surveymonkey.com; SPSS Inc). Responses to open questions were coded using QSR NVivo software (QSR International Pty Limited).

\section{Results}

Response Rate

Table 1 illustrates that a total of 108 of 163 participants responded (response rate of $66 \%$ ).

TABLE 1 The survey sample by professional grade and response rate

\begin{tabular}{lcccc}
\hline $\begin{array}{l}\text { Employment } \\
\text { Position of } \\
\text { Participant }\end{array}$ & $\begin{array}{c}\text { Number in } \\
\text { Population }\end{array}$ & $\begin{array}{c}\text { Number } \\
\text { in Sample }\end{array}$ & $\begin{array}{c}\text { Number of } \\
\text { Respondents }\end{array}$ & $\begin{array}{c}\text { Response } \\
\text { Rate }\end{array}$ \\
\hline Head of Library & 21 & 13 & 10 & $77 \%$ \\
$\begin{array}{l}\text { Deputy Librarian } \\
\text { Sub Librarian }\end{array}$ & 22 & 13 & 12 & $92 \%$ \\
Faculty Librarian & 16 & 10 & $11^{*}$ & $100 \%$ \\
Systems Librarian & 20 & 25 & 8 & $32 \%$ \\
Assistant Librarian & 150 & 90 & 7 & $58 \%$ \\
Other & 271 & 163 & 54 & $60 \%$ \\
Total: & & & 108 & $66 \%$ \\
\hline
\end{tabular}

*One Subject Librarian classified herself as a Sub-Librarian. She would have been classified as an Assistant Librarian in the original sample.

${ }^{* *}$ The 6 "Other" respondents would have been variously categorized as 5 Faculty Librarians and 1 Assistant Librarian in the original sample, and their responses have been reallocated for the data analysis. 
Thirty seven $(34.3 \%)$ participants indicated they were prepared to be interviewed and interviews eventually obtained with 25 respondents (68\% of the participants who agreed, $23 \%$ of the 108 original participants).

Sixty eight $(63 \%)$ of the library managers surveyed were employed in University libraries and $40(37 \%)$ in Institute of Technology libraries. Ten $(40 \%)$ of the library managers who participated in subsequent interviews were employed in University libraries and $15(60 \%)$ in Institute of Technology libraries.

The substantive questions in the questionnaire addressed research issues which remained unanswered in the literature as detailed in the following sections.

\section{What was Academic Library Managers' Level of Awareness of the Duty to Accommodate?}

Questionnaire responses indicated a high level of awareness $(\mathrm{n}=$ $107 / 108,99.1 \%$ ) of the duty to provide reasonable accommodation for employees with a disability.

What were Academic Library Managers Actual Perceptions of Disability?

Participants were presented with a vignette in order to test whether they subscribed to the medical or social model of disability (Figure 1).

Of the total 108 participants $68(63 \%)$ sympathized with John's perspective suggesting significant level of support for the

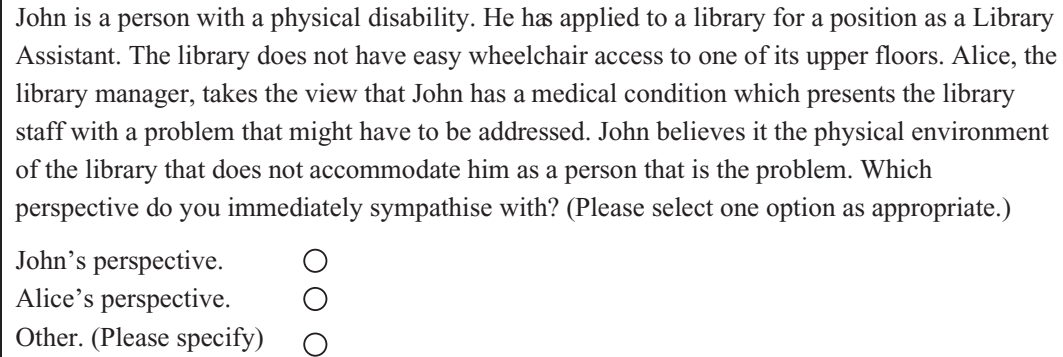

FIGURE 1 Vignette to discern academic library managers' perceptions of disability. 
TABLE 2 How different library manager grades perceive disability

\begin{tabular}{lcccc}
\hline & $\begin{array}{c}\text { Social } \\
\text { Model }\end{array}$ & $\begin{array}{c}\text { Medical } \\
\text { Model }\end{array}$ & $\begin{array}{c}\text { Mixed } \\
\text { Model }\end{array}$ & $\begin{array}{c}\text { Other } \\
\text { Responses }\end{array}$ \\
\hline Head Librarian & 10 & 0 & 0 & 0 \\
Deputy Librarian & 4 & 3 & 5 & 0 \\
Sub-Librarian & 8 & 3 & 0 & 0 \\
Faculty Librarian* & 6 & 1 & 4 & 2 \\
Systems Librarian & 4 & 2 & 1 & 0 \\
Assistant Librarian** & 36 & 11 & 6 & 2 \\
\hline
\end{tabular}

*Includes 5 originally classed as Other, Table 1.

** Includes one originally classed as Other, Table 1.

social model of disability. Twenty (18.5\%) participants agreed with Alice's perspective suggesting some support for the medical model of disability. Surprisingly, 20 (18.5\%) participants indicated a choice of another viewpoint. Of these, 16 (14.8\%) participants were of the view that both perspectives were valid. Of the remaining four participants, three pointed to the practical difficulties of major architectural structuring to accommodate one person and one participant pointed to the need for John to be given the support of the wider library team on taking up employment.

There were differences among staff groups on attitudes (Table 2). A test of association (Chi-test) examining preferences for the social as opposed to the medical/mixed model (including other responses) found that heads and sub-librarians (as a group) were significantly more likely to subscribe to the social model than the grouping of faculty, systems, assistant and (surprisingly) deputy librarians $\left(\chi^{2}=5.84, p=0.02,1\right.$ degree of freedom).

Did Academic Library Managers Perceive the Accommodation Needs of Library Employees and Library Clients with Disabilities as Different?

A vignette (Figure 2) was used to check whether library managers' views differed in relation to accommodation of library clients and library employees with disabilities. 


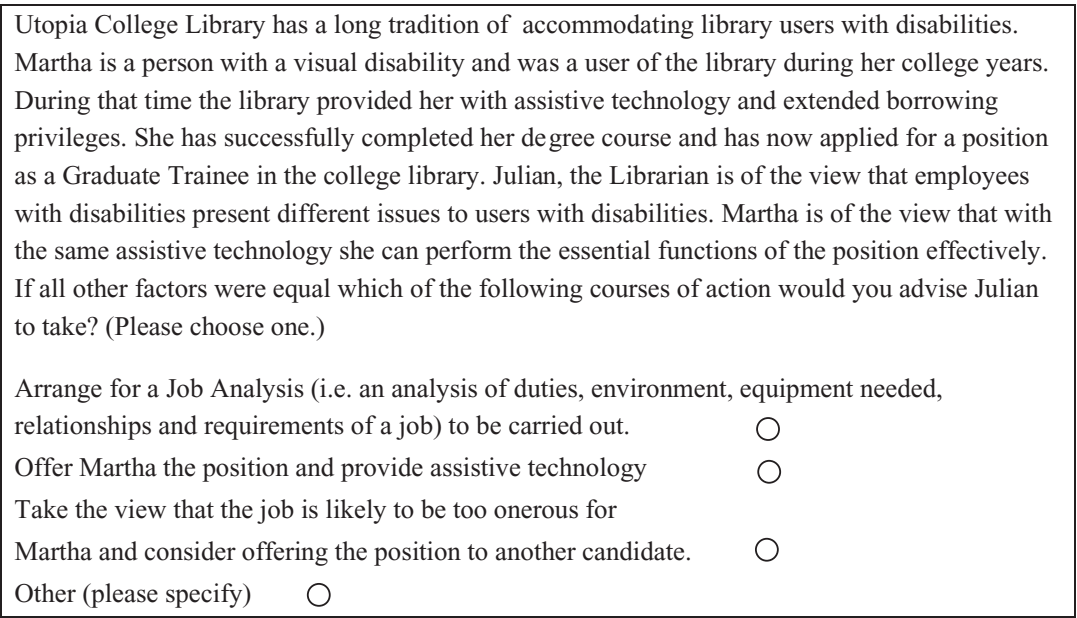

FIGURE 2 Vignette to discern whether academic library managers distinguished between the accommodation needs of library clients and library employees with disabilities.

When the responses to this vignette were analyzed a majority, $(\mathrm{n}=74,68.5 \%)$ of participants chose the option "Arrange for a job analysis ... to be carried out" suggesting that a majority of library managers would adopt an approach to meeting the accommodation needs of an employee with a disability which was different to meeting those of a library client with disabilities and the approach would be led by the requirements of the position. Twentythree $(21.3 \%)$ of participants chose the option "Offer Martha the position and provide assistive technology," suggesting that the needs of library clients and employees would be addressed in the same manner. One $(0.92 \%)$ participant chose the third option, namely, "Take the view that the job is likely to be too onerous for Martha ..." and 10 participants chose the option "Other," mostly offering a compromise between the first two options. In interviews, respondents explained some of the differences required for accommodation of employees; in particular, they referred to the significant time likely to be spent interacting with colleagues and clients, the provision of specific work equipment, and the time constraints on task completion. 
Were Library Managers Aware of the Accommodations for Library Employees with Less Visible Disabilities?

When asked how an employee with a hearing disability might be accommodated, solutions fell into four general categories: Assistive Technology Accommodation where participants indicated that technology would assist the employee; Job Structuring Accommodation where participants indicated that offering the employee a position where his/her disability would not be a disadvantage would be the solution; Facilitator Accommodation - where the services of a Job Coach or a sign language interpreter would be engaged; and Supportive Accommodation where the support of colleagues would be offered. Solutions focused largely on enabling the employee with a disability to complete work effectively and efficiently.

For accommodation of employees with a mental health disability, interactions with clients and colleagues were clearly the main issue, with work-related stress a secondary one. The most popular solutions were to provide personal and counseling support to the employee within the organization $(n=24)$; to allocate the employee to less stressful non-frontline duties $(n=23)$; to provide disability awareness training to staff to increase understanding of mental health difficulties $(\mathrm{n}=19)$; and with other suggestions mostly variations on these themes, apart from those had no clear ideas $(n=12)$.

\section{Did Academic Libraries have Accommodation Procedures in Place?}

Most $(62 / 108,57.4 \%)$ stated that their library did have a procedure for accommodation in place. Thirty-seven (34.3\%) indicated that they did not and nine participants $(8.3 \%)$ did not answer the question. Replies indicated that University libraries were more likely to have procedures for accommodation than Institute of Technology libraries.

\section{What Proportion of the Library Budget were Library Managers Prepared to Spend on Accommodation?}

The majority of library managers $(86 / 108)$ indicated that they were prepared to spend no more than $10 \%$ of the library budget on accommodation. Most academic library budgets are agreed on 
an annual basis so this percentage generally reflected annual expenditure on accommodation.

Are Sanctions for Failure to Provide Accommodation Necessary?

On the question of legal sanctions to ensure compliance, a small majority $(60 / 108,55.5 \%)$ replied that they deemed them necessary. Of those who believed in sanctions, just over half $(32 / 60$, $53 \%$ ) reported their library as having a procedure in place. Of those who held the opposite view $(\mathrm{n}=46)$, a larger proportion $(29 / 46,63 \%)$ had a procedure in place. However, there was no significant association between belief in sanctions and presence of an accommodation procedure $\left(\chi^{2}=0.32, \mathrm{p}=0.89,1\right.$ degree of freedom).

Are Library Managers Willing to Act to Address Integration Difficulties Experienced by Employees with Less Visible Disabilities?

The final vignette explored reactions to a difficult integration issue (see Figure 3).

Of the total 108 participants surveyed three $(2.8 \%)$ participants chose the first option, whereas sixty-nine $(63.8 \%)$ chose the option "Discuss Maisie's reservations with her and arrange for all staff to attend disability awareness training." Fifteen (13.9\%) participants

Robert has been an employee of the library for ten years. Four years ago he was diagnosed with
manic depressive disorder. His condition is well managed with medication. Robert has made his
condition known to one or two members of staff. Maisie, a new member of staff in his section,
has learned of Robert's difficulty and has indicated that she would prefer not to work with
someone who has a mental health difficulty. How would you deal with the situation?
Review Robert's position and examine possibilities for situating him in other departments that
would not be detrimental to his career prospects.
Discuss Maisie's reservations with her and arrange for all staff to attend disability awareness
training.
Arrange for a performance appraisal meeting with Maisie and suggest disability awareness
training.
Do nothing, assuming Maisie's fears will be short-lived.
Other. (Please specify).

FIGURE 3 Vignette to discover what action an academic library manager would take to deal with a difficult integration issue in the workplace. 
chose the option "Arrange for a performance appraisal meeting with Maisie and suggest disability awareness training." Twenty-one (19.4\%) chose the option "Other." Their reasons for doing so were wide and varied, but 13 (12\%) participants indicated that they would prefer to discuss Maisie's reservations with her and arrange for her alone to attend disability awareness training. No participants chose the "Do nothing" option.

\section{Discussion}

Conflicting Perceptions of Disability among Library Managers

As has been mentioned in a previous section, there are two distinct perspectives on disability to be found in the disability debate: the "medical model" and the "social model." The social model of disability finds its conceptual origins in pre-industrial revolution societies where a useful role was found for individuals in the economic life of the society. The industrial revolution with its focus on minimizing the cost of production and maximizing profits in industrial production effectively marginalized people who experienced "incapacity to present themselves as wage labourers" and created a class of people with disabilities who were deemed "dependent" (Thomas, 38). This led to the perception that, they, as individuals presented a problem in medical terms that it was not the responsibility of employers but rather medical practitioners to address. It is this "medicalized" perception which the modern movement seeks to correct as it fails to recognize the potential contribution that people with disabilities can make to society.

The fact that the results of the study revealed that Heads of Library services identify strongly $(100 \%)$ with the social model might be said to reflect the ability of Heads of Libraries to absorb emerging political norms and/or a willingness to accommodate on the part of those charged with making accommodation decisions. The same might be said (although to a lesser extent) of responses of Sub-Librarians (72\%), Systems (57\%), and Assistant Librarians $(65 \%)$, who, in practice, have most experience of assisting clients with disabilities on a daily basis - Sub-Librarians and Systems Librarians in customizing Web technologies and Assistant Librarians in dealing with clients with disabilities at the desk and 
on the floor of the library so that their expressed alignment with the social model may have a closer connection to practice.

Surprisingly $14.8 \%$ of respondents $(n=16)$ suggested a third and "other" point of view not offered as a response to the vignette, namely, that both perspectives were valid, indicating that in approaching disability matters they would see the issues both in terms of an individual and a societal issue. This hybrid view held, particularly by Deputy Heads of Libraries $(n=5,42 \%)$ and to a lesser extent, Faculty Librarians $(\mathrm{n}=4,31 \%)$, may be explained either (a) as a failure to move completely from the medical model or (b) as difficulties in balancing risks and responsibilities so as to put in place the practical solutions that the social model requires.

\section{Differences in Approach to Accommodating Library Employees and Library Clients with Disabilities}

The results of the vignette revealed that, all other factors being equal, a majority $(68.5 \%)$ of 108 library managers would actually approach the matter of the employment and accommodation of an employee with a disability in a different manner to the accommodation of a client with a disability-their approach being of conducting a job analysis before recruiting being endorsed by the IBEC/ICTU Workway Disability and Employment Guidelines ("the IBEC/ICTU Workway Guidelines") drawn up by the Irish Business and Employers' Confederation ("IBEC") and the Irish Congress of Trade Unions ("ICTU") (41-42).

\section{How do Academic Library Managers Approach the Accommodation of Employees with Less Visible Disabilities?}

What is apparent from the study's findings on the issue of less visible disabilities is that academic libraries' reputation and experience in the area of accommodation of visible disabilities and in encouraging accessibility in that field has not yet filtered through to the area of accommodation of less visible disabilities. Where hearing disability was concerned, it appeared that library managers were not generally aware of the different types of hearing disability, namely: (1) people who are hard of hearing, (2) people who are deaf and became so in adulthood, and (3) people who are born deaf or became deaf early in life and their 
different accommodation requirements (although it is possible that the constraints of the online survey text box prevented survey participants from answering more fully). By contrast, Cornell University's brochure entitled Working Effectively with Persons Who are Hard of Hearing, Late Deafened or Deaf describes these categories of disability in detail and their distinct accommodation needs.

In addition, survey participants appeared to be aware only in general terms of some of the types of assistive technology available to employees with a hearing disability (e.g., general loop technology, portable hearing loops, a fire alarm system with flashing lights, good electronic signage, telephone to text technology, and "appropriately adapted" telephones). When these examples are compared with the Assistive Technology accommodations listed in the IBEC/ICTU Workway Web site, it will be apparent that the potential accommodations are substantially more wide ranging and extensive. It is also possible that staff with hearing difficulties might be reluctant to disclose their disability. One interviewee referred to this element of self-reliance. This leads to one of the difficulties of accommodation: without knowledge of the disability, the library manager cannot offer accommodation.

Where mental health difficulties were concerned it was also apparent that survey participants were aware, but only in general terms, of the types of accommodation available to employees with mental health difficulties. Survey responses also confirmed the problems of stigma and lack of understanding for employees with mental health difficulties that may have contributed to the lack of knowledge of accommodations and identified the need for disability awareness training for both managers and staff.

On the other hand, unexpectedly, participants in the survey and subsequent interviews did suggest some ways not previously canvassed in the literature in which employees with less visible disabilities could be accommodated in libraries. For example, job structuring and allocation accommodations and the support of colleagues for both staff members with a hearing disability and staff members with mental health difficulties featured in library managers' survey responses. In some instances library managers identified accommodation needs that were also to be found in the literature. Where employees with mental health difficulties were in issue, the survey responses expressed a concern that there be 
good communication between manager and the employee with a mental health difficulty and that $\mathrm{s} /$ he receive appropriate mentoring and supervision and relevant training. The need for good management practice in this regard is forthrightly reflected in Cornell University's brochure entitled Employing and Accommodating Workers with Psychiatric Disabilities (2).

Survey responses varied on flexible working conditions for employees with less visible disabilities, in particular, employees with mental health difficulties. Just three participants suggested flexibility in deciding on work locations and the person's working time (Participants 114, 153, 55); one suggested providing suitable accommodation for the employee (Participant No.112) and one participant suggested the provision of pro-rata reward for attendance and performance of duties (Participant No. 46). This may, perhaps, indicate some reluctance on the part of library managers to change working patterns for an employee with a mental health difficulty where there is an impact on those of other staff. By contrast, Cornell University's brochure suggests that employees with mental health difficulties may benefit from a broad variety of flexible working accommodations.

The overall picture presented in relation to accommodation of employees with less visible disabilities is one of a lack of specific knowledge on the part of library managers of the needs of, and accommodations for, the staff with the less visible disability but a willingness to consider ways of accommodating them where their disability would not place them at a disadvantage.

\section{Have Academic Libraries Heeded Judicial Concern and Put Accommodation Procedures in Place?}

A reasonable accommodation procedure for staff already in employment would typically address such matters as when and how disability should be disclosed; the initial meeting between the employee and the managers; the nature of the medical evidence required; the carrying out of a needs assessment; the nature of the recommended accommodation; the submission of the accommodation request to the person in charge of college facilities; and the review of the accommodation arrangements (Trinity College Dublin, 31-34). 
The survey results indicated that while over $99 \%$ of academic library managers were aware of the legal duty to accommodate and that while some progress had been made in implementing procedures, one third $(34.3 \%)$ of library managers overall reported that their college did not have a procedure in place and the Institute of Technology libraries had made less progress than the University libraries. This would seem to indicate that library managers' current "awareness" is passive and does not wholly translate into practical compliance. In practical terms, it means library staff with disabilities wishing to present a request for accommodation to a library manager will be confronted by an extra burden, the lack of precedent and accepted practice.

\section{Do Library Managers Have a Realistic Perception of the Costs of Accommodation?}

The survey results and interview findings confirm that survey participants had a realistic appreciation of the cost of accommodation. Survey results in other jurisdictions indicate the cost of accommodating employees with disabilities is in fact quite low. The Job Accommodation Network ("JAN") a service of the United States President's Committee on the Employment of People with Disabilities reported that the average cost of an accommodation is $\$ 200$, with $17 \%$ of those surveyed reporting that the accommodations cost nothing; $52 \%$ reporting a cost of less than $\$ 500$; and $10 \%$ reporting that the cost was between $\$ 501$ and $\$ 1,000$ (Bruton 11).

What seems to be in issue in the costs debate is that the "perceived" costs of accommodating disability in libraries are greater than they are in reality. Most library managers were apologetic about choosing $0-10 \%$ of their budget as the appropriate accommodation allocation when, in fact, in the majority of cases this is likely to be sufficient to meet, or indeed, exceed, the cost of accommodation.

\section{How do Library Managers Approach Difficult Integration Issues?}

A vignette presented survey participants with a scenario involving potential discrimination and difficulties between a new recruit to a library and an established employee with a well-managed 
mental health difficulty in order to ascertain to what extent library managers are prepared to act positively to defend the principle of "equality of opportunities" in the case of an invisible disability.

The results and findings suggest cautious support for the principle where the disability in issue is an invisible one. It appears from the survey results that a majority $(n=69,63.8 \%)$ of library managers are likely to adopt an informal approach initially but prepared to move toward more formal approaches when a diversity problem persists. They also reflect a particular concern (expressed as "Other" in the survey responses) to deal with diversity issues as proportionately, appropriately, and confidentially as possible $(\mathrm{n}=21,19.4 \%)$. A minority $(\mathrm{n}=15,13.9 \%)$ would opt for an initial formal approach when a discriminatory situation presented.

A perceptible diffidence in response may indicate a need for library managers to receive induction training in awareness of invisible disabilities and in handling difficult diversity issues in the workplace so that they will be equipped with the psychological and procedural knowledge to offer the necessary support to people with disabilities either visible or invisible in the workplace (Crowther et al. 207)

\section{Conclusion}

The most significant findings of this study were:

1. Academic library managers do perceive the needs of employees with disabilities as different from those of clients with disabilities.

2. Appreciation of the view that disability is a socially created construct is relatively high among library managers (63\%) in contrast to the medical view of disability as a matter personal to the individual $(18.5 \%)$ with some surprising support (14.8\%) for a hybrid "social/medical" model, particularly among Deputy Heads of Libraries and Faculty Librarians, suggesting difficulty with strict dichotomies.

3. Academic library managers have a general knowledge of the needs of, and accommodations for, employees with less visible disabilities such as hearing disability and mental health difficulty, but more detailed awareness and accommodation 
training is required to enable colleges to be pro-active and, therefore, more responsive to the needs of employees with less visible disabilities.

4. An overwhelming majority of academic library managers are aware of their legal duty to accommodate employees with disabilities but this does not always translate into practice.

5 . One third $(34.3 \%)$ of library managers reported that their college library did not have a procedure in place to address a request from employees with disabilities for reasonable accommodation despite judicial rulings that they should be in place. Institute of Technology library managers reported least compliance $(42 \%)$.

6. A small majority (55\%) of library managers believe that a legal obligation and sanction is necessary if college libraries are to comply with the duty to provide reasonable accommodation. A minority $(42.6 \%)$ of library managers believe that the professional library "ethos" of accommodating need will, in itself, bring about compliance, but there is slight if insignificant statistical support for this view.

7. A significant majority ( $80 \%$ ) of library managers indicated that they would be relatively conservative in their spending on accommodation of employees with disabilities, favoring allocation of between $0-10 \%$ of the library budget to such accommodation. However, library managers appear not to realize that, in most cases, this is an adequate amount.

8. A majority $(63.8 \%)$, of college library managers are prepared to take a cautious but positive approach to deal with integration issues in the library where a disability is not visible, moving toward a more formal and negative approach if the difficulty persists. More training in disability awareness and procedural issues is required if college library managers are to be more confident in their approach.

These findings represent the situation in 2009, and further research could verify whether the trends toward a more general awareness of the social model of disability had occurred, and whether the differences among grades of staff had eroded. The research suggested that views could vary among qualified staff with practical experience of dealing with clients with a disability. The views, specifically, of library staff with disabilities should 
be sought to provide greater understanding of accommodation in practice and the views of non-qualified staff ascertained to determine their training needs. Future research could examine the impact of training in disability awareness.

\section{References}

The Aisling Foundation. Ready Willing and Able: An Employer's Guide to Hiring People with a Disability. Dublin: Aisling Foundation, 2006. Print.

Boyle v. Department of Social and Family Affairs. No. DEC-E2005-032. Equality Officer. 7 July 2005. Irish Employment Law Journal 2.4 (2005): 132. Print.

Bruton, Claire. "Reasonable Accommodation in Disability Discrimination Law." Irish Employment Law Journal 2.1 (2005): 9-16. Print.

Bryman, Alan. Social Research Methods. 3rd ed. Oxford: Oxford University Press, 2008. Print.

Burke, Ronald, J. "Disability and Women's Work Experience: An Exploratory Study." International Journal of Sociology and Social Policy 19.2 (1999): 21-33. Print.

Byrne, Raymond. "Equality and Disability: The Need for a Comprehensive Response.” Irish Law Times, 12.7 (1994): 157. Print.

Canadian Mental Health Association. Mental Health Works. 2007. Web. 27 Aug. 2007. <http://mentalhealthworks.ca/>.

Charles, Sandra. "Person First, Disability Second: Disability Awareness Training in Libraries." Library Review 54.8 (2005): 453-58. Print.

Christie, Lauri, and Brian H. Kleiner. "New Developments Concerning Reasonable Accommodation of Disabilities in American Organisations." Equal Opportunities Review 20. 5/6/7 (2001): 152-56. Print.

Conroy, Pauline, and Sarah Fanagan. Research Project on the Effective Recruitment of People with Disabilities into the Public Service, 2000. Dublin: Equality Authority and Department of Justice, Equality and Law Reform, 2001. Print.

Cornell University. "Working Effectively with Persons who are Hard of Hearing, Late Deafened or Deaf." 2002. Web. 6 Apr. 2010. < http:/ / digitalcommons.ilr. cornell.edu/edicollect/11/>.

Cornell University. "Employing and Accommodating Workers with Psychiatric Disabilities.” Cornell.edu. 2000. Web. 6 Apr 2010. <http://digitalcommons. ilr.cornell.edu/edicollect/5/>.

Creative Research Systems. "Sample Size Calculator." 2007-2010. Web. 18 Aug. 2009. <http://www.surveysystem.com/sscalc.htm>.

Crowther, Ruth E., Max Marshall, Gary R. Bond, and Peter Huxley. "Helping People with Severe Mental Illness to Obtain Work: Systematic Review." British Medical Journal 222 (2001): 204-08. Print.

Dibben, Pauline, Phil James, and Ian Cunningham. "Senior Management Commitment to Disability: The Influence of Legal Compulsion and Best Practice." Personnel Review 30.4 (2001): 451-467. Print. 
Dibben, Pauline, Phil James, Ian Cunningham, and David Smythe. "Employers and Employees with Disabilities in the UK: An Economically Beneficial Relationship?” International Journal of Social Economics 29.6 (2005): 453-467. Print.

An Employee v. Bus Eireann. No. DEC-E2003-004. Equality Officer. 4 February 2003. Employment Law Reports 14 (2003): 351. Print.

In the matter of the Employment Equality Bill 1996. Supreme Court. 15 May 1997. Irish Reports 2 (1997): 321. Print.

Equality Act 2004. No. 24 of 2004. 18 Jul. 2004. Print.

Equality Act 2010. 2010 Chapter 15. 8 Web. Apr. $2010<$ http://www.equalities. gov.uk/equality_act_2010.aspx>.

Finch, Janet. "Research Note: The Vignette Technique in Survey Research." Sociology 21.1 (1987): 105-114. Print.

Forrest, Margaret. E. S. "Disability Awareness Training for Library Staff: Evaluating an Online Module." Library Review 56.8 (2007): 707-15. Print.

Frankfort-Nachmias, Chava, and David Nachmias. Research Methods in the Social Sciences. (5th ed.). London: Holder Arnold, 2005. Print.

Gillham, Bill. Research Interviewing: The Range of Techniques. Maidenhead: Open University Press, 2005. Print.

Hosking, David L. "Great Expectations: Protection form Discrimination because of Disability in Community Law." European Law Review 31.5 (2006): 667-89. Print.

Hosking, David L. “A High Bar for EU Disability Rights." Industrial Law Journal 36 (2007): 228-37. Print.

IBEC/ICTU. "IBEC/ICTU Workway Disability and Employment Guidelines." n.d. Web. 26 Apr. 2010. <http://www.workway.ie/>.

IBEC/ICTU. Workway. 2007. Web. 9 Sep. 2007. <http://workway.ie/>.

Ireland Department of the Environment and Local Government. Code of Practice for the Employment of People with Disabilities in the Local Authority Service. Dublin: Department of the Environment and Local Government, 1999. Print.

Ireland Department of Finance. Employment of People with Disabilities: Code of Practice. Dublin: Department of the Environment and Local Government, 1994. Print.

Irish Employment Equality Act 1998. No. 21 of 1998. 18 Jun. 1998. Print.

Irving, Cathy, and Brian H. Kleiner. "New Developments Concerning Reasonable Accommodation of Disabilities in American Organizations." Equal Opportunities International 18.5/6 (1999): 238-43. Print.

Joint, Nicholas. "Disability Issues and Libraries: a Scottish Perspective." Library Review 54.8 (2005): 449-52. Print.

Joint, Nicholas. “Libraries, Digitisation and Disability." Library Review 55.3 (2006): 168-72. Print.

Mancuso, Laura. "Achieving Reasonable Accommodation for Workers with Psychiatric Disabilities: Understanding the Employer's Perspective.” American Rehabilitation Spring (1995): 2-8. Print.

McCaskill, Kirsty, and Ann Goulding. "English Public Library Services and the Disability Discrimination Act.” New Library World 102.1165 (2001): 192-206. Print. 
McCrann, Terence, and Mary Kelleher. "Disability Discrimination under the Employment Equality Act 1998 and the Equality Bill 2004." Irish Employment Law Journal 1.2 (2004): 42-47. Print.

Nelson, Jennifer, and Brian H. Kleiner. "How to Accommodate Common Disabilities in Organisations.” Equal Opportunities International 20.5/6/7 (2001): 146-51. Print.

Newton, Rita., Marcus Ormerod, and Pam Thomas. "Disabled People's Experiences in the Workplace Environment in England." Equal Opportunities International 26.6 (2007): 610-23. Print.

Office of Disability Employment Policy. U.S. Department of Labor. Job Accommodation Network. JAN. 2007. Web. 9 Sep. 2007. <http://www.jan.wvu.edu/>.

O’Mara, Ciaran. "European Court Defines 'Disability.”' Irish Employment Law Journal 3.3 (2006): 102-03. Print.

NVivo. Vers. 8. Doncaster, Victoria: QSR International Pty Limited, 1999-2009. CD ROM.

Sahi, Sanjit, and Brian H. Kleiner. "Reasonable Accommodation of Psychiatric Disability under the ADA.” Equal Opportunities International 20.5/6/7 (2001): 133-37. Print.

Sapsford, Roger, and Victor Jupp, eds. Data Collection and Analysis. 2nd ed. London: Sage Publications, 2006. Print.

Smith, Theresa. "Diversity and Disability: Exploring the Experiences of Vision Impaired People in the Workplace.” Equal Opportunities International 21.8 (2002): 59-72. Print.

Spechler, Jay. W. Reasonable Accommodation: Profitable Compliance with the Americans with Disabilities Act. Florida: St Lucie Press, 1996. Print.

SPSS for Windows. Vers. 16. Chicago: SPSS Inc, 2010. CD ROM.

Surveymonkey.com 1999-2010. Web. 20 Aug. 2008. <http://www.surveymonkey. $\mathrm{com} />$.

Thomas, Carol. "Developing the Social Relational in the Social Model of Disability: A Theoretical Agenda.” Implementing the Social Model of Disability: Theory and Research. Eds. Colin Barnes and Geof Mercer. Leeds: The Disability Press, 2004: 32-47. Print.

Trinity College Dublin. "Supporting Staff with Disabilities: Guide for Staff and Managers." Nov. 2008. Web. 3 May 2010. <http://tcd.ie/disability/ staff/staff_with_disab.php $>$.

Uppal, Sharanjit. "Disability, Workplace Characteristics and Job Satisfaction.” International Journal of Manpower 26.4 (2005): 336-49. Print.

Urbaniak, Geoffrey C., and Scott Plous. Research Randomizer. 2008. Web. 15 Nov. 2008. <http://www.randomizer.org/form.htm/>.

Urquhart, Christine J. (1999). "Using Vignettes to Diagnose Information Seeking Strategies: Opportunities and Possible Problems for Information Use Studies of Health Professionals." Exploring the Contexts of Information Behaviour: Proceedings of the 2nd International Conference in Research in Information Needs, Seeking and Use in Different Contexts, 13-15th August 1998. Eds. Thomas D. Wilson and David K. Allen. London: Taylor Graham, 1999: 277-89. Print.

Waddington, Lisa, and Aart Hendriks. "The Expanding Concept of Employment Discrimination in Europe: From Direct and Indirect Discrimination to Rea- 
sonable Accommodation Discrimination.” International Journal of Comparative Labour Law and Industrial Relations, Winter (2002): 403-27. Print.

Wells, Katie. "The Impact of the Framework Employment Directive on UK Disability Discrimination Law.” Industrial Law Journal 32.4 (2003): 253-73. Print.

Wendt, Ann C., and William M. Slonaker, Sr. "ADA's Reasonable Accommodation: Myth or Reality.” SAM Advanced Management Journal Autumn (2007): 21-31. Print.

A Worker (Mr. O) v. An Employer (No. 1). No. EDA0419. Labour Court. 5 January 2005. Employment Law Reports (2005): 113. Print. 